\title{
PHYSIOLOGICAL CHANGES OF CULTIVATED EGGPLANT (SOLANUM MELONGENA L.) IN RESPONSE TO WATER DEFICIT
}

\author{
AL-MUWAYHI, M. A. \\ Department of Physics and Chemistry, Faculty of Science, Shaqra University \\ P.O. Box 33, Shaqra, 11961, Kingdom of Saudi Arabia \\ (e-mail:malmuwayhi@su.edu.sa; phone: +966-11-6224-4118) \\ (Received $5^{\text {th }}$ Sep 2019; accepted $15^{\text {th }}$ Nov 2019)
}

\begin{abstract}
The effects of drought on the physiology of eggplants (Solanum melongena L. cv., Madona) were studied. Drought stress treatment had been done by irrigating the plants with $80 \%, 60 \%$ and $40 \%$ of water needed to reach soil pot capacity, plus normal irrigation (control treatment). The objective of this research was to reveal physiological response of eggplant to different levels of drought stress, as well as, its nutrient. The obtained results showed that, nutrients concentrations of the studied eggplants grown in pots under different irrigation treatments decrease according to water stress levels. Drought stress significantly reduced the ammount of total chlorophyll, chlorophyll a, chlorophyll b and total carotenoids resulting in damaged leaves. Carotenoids decreased in response to water stress from $8.65 \mathrm{mg} / \mathrm{g} \mathrm{FW}$ under control in comparison to $5.84 \mathrm{mg} / \mathrm{g} \mathrm{FW}$ the fourth water deficit treatment. All water stress treatments increased the accumulation of proline content in plant. Lack of water in plant modified anti-oxidative enzyme activities in order to alleviate the water stress. The results indicate that irrigation treatment with $80 \%$ of pot capacity have more efficient water use than $60 \%$ and $40 \%$, which reduces drought stress and improves ionic balance of the plants.
\end{abstract}

Keywords: eggplant, water stress, nutrients, antioxidant enzymes, pigments, proline

\section{Introduction}

Eggplant (Solanum melongena L.) is a popular nightshade crop plant commonly cultivated in tropical and subtropical farmland. The stunted growth, lack of yield and poor quality of plant product caused by water stress has been well studied by researchers and agriculturists, and many physiological processes involved for this reduction in variable crop plants. Many studies has been carried out in Asia, Africa, Europe and different region on eggplant irrigation (Gaveh et al., 2011; Karam et al., 2011) showing that eggplant can be produced at moderate levels of water stress without severe effect on fruit yield. There is a complex relationship between yield, physiological responses and vegetative growth to different level of water stress, especially in eggplant under semi-arid conditions (Kirnak et al., 2001). Plants experience water stress during intense transpiration rate or when there is limited water supply around their roots. Plants attempt to eleviate the negative effect of drought stress using a set of biochemical and physiological mechanisms.

Concerning water scarcity, Saudi Arabia is an arid high temperature zone and faced with increased competitions for water resources between different sectors (agriculture, industry or domestic consumption). So economic and effective irrigation regimes is an important matter to solve.

High yield of crop production and water savings are some of the benefits in optimizing irrigation water management. Appropriate strategies in agriculture practices are need to be found to get efficient use of limited water in semi arid zones. Abd ElGhany et al. (2004) stated that the identified varieties that had high and/or moderate 
yield potential besides desirable specific adaptation traits are useful for drought stress and could be combined to achieve optimum performance. One important strategy is to better manage water and increase its productivity (Molden, 1997; Molden et al., 2001; Gupta et al., 2016; Tani et al., 2018). Effective irrigation scheduling needs to be designed to ensure the optimal use of limited water. Díaz-Pérez and Eaton (2015) indicated that eggplant may tolerate moderate drought stress, since plants watered at 67\% Evapotranspiration level (Etc). A comprehensive knowledge of drought stress effect on plants is critical to enhanced management practices and crops breeding efforts in agriculture under semi arid condition. Many works in this field were developed over the past twenty years, covering topics from plant approaches to control water status under drought, to the physiological and biochemical processes underlying plant response to water deficits (Chaves, 1991; Cornic and Massacci, 1996; Kurniawati, 2014; Buhtz et al., 2017). Kurniawati (2014) found that during the drought treatment, plant growth, biomass, media water content, relative water content, chlorophyll content concentration were reduced while proline and polyamines were increased and reached the high levels on 14 to 21 days after the treatment.

The present research was carried out to study the effect of drought stress on physiological characters of studied eggplants, i.e., leaf chlorophyll, carotenoids, proline and enzyme activity, as well as, some nutrients (K, P, C and N) uptake.

\section{Materials and Methods}

Within the experimental researches to evaluate many of solanaceae plants at the

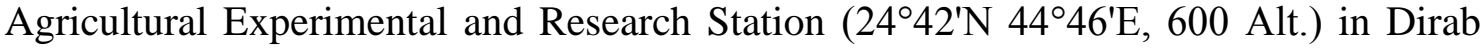
region, Saudi Arabia, during the spring growing season (March to June), it is worth mentioning like research Almohisen (2015). Seeds had been planted at nursery in greenhouse until seedlings have three foliage leaves and reached $15 \mathrm{~cm}$ shoot height, then were transported to $30 \mathrm{~cm}$ pots size $(30 \mathrm{~cm}$ top dimeter, $25 \mathrm{~cm}$ base dimeter and $30 \mathrm{~cm}$ pot height) after filled with sandy loam (1:1) media in the outfield. Irrigating treatment started on $1^{\text {st }}$ of March and the harvest were done on 1st of June. All agronomy practices and plant protection had been done according to the agricultural region. Randomized complex block design with three replications were used. Soil physical and chemical properties measured according to Cassel and Nielsen (1986), Klute et al. (1986) and Rhoades (1982). Also, chemical properties of irrigation water were estimated according to Bock (1984) as shown in Table 1.

\section{Irrigation treatments}

Irrigation treatments depended on measuring the deficit of soil moisture contents from the pot capacity, the potential evaporation was calculated using the Pan evaporation as described by Richards (1969). Irrigation treatments included 4 levels of water deficit stress that were control T1 (100\% pot capacity), T2 (80\% pot capacity), T3 (60\% pot capacity) and T4 (40\% pot capacity).

\section{Physiological parameters}

Elements were estimated according to Doorenbos (1975). Regarding to Chlorophyll and carotenoid content, the extraction of leaf pigments was performed with $80 \%$ acetone, and the absorbance at 663 and $645 \mathrm{~nm}$ was measured with an Ultrospec 2100 
pro spectrophotometer (Amersham Biosciences). Total carotenoid content, chlorophyll $\mathrm{a}$, chlorophyll $\mathrm{b}$, and total chlorophyll quantities were calculated according to the method of Arnon (1949) using the following formula:

$$
\begin{aligned}
& \mathrm{A}_{663}=82.04 \mathrm{Chl}_{\mathrm{a}}+9.27 \mathrm{Chl}_{\mathrm{b}} \\
& \mathrm{A}_{645}=16.75 \mathrm{Chl}_{\mathrm{a}}+45.6 \mathrm{Chl}_{\mathrm{b}}
\end{aligned}
$$

where $\mathrm{A}$ is the density values at the respective wavelengths as obtained on the spectrophotometer and $\mathrm{Chl}_{\mathrm{a}}, \mathrm{Chl}_{\mathrm{b}}$ are grams per liter of chlorophyll a and $\mathrm{b}$, respectively. From the solving previous equations we will obtain the following:

$$
\begin{gathered}
\text { Chl a }(\mathrm{mg} / \mathrm{l})=12.7\left(\mathrm{~A}_{663}\right)-2.69\left(\mathrm{~A}_{645}\right) \\
\mathrm{Chl} \mathrm{b}(\mathrm{mg} / \mathrm{l})=22.9\left(\mathrm{~A}_{645}\right)-4.68\left(\mathrm{~A}_{663}\right) \\
\text { Total Chl }(\mathrm{a} \text { and } \mathrm{b})(\mathrm{mg} / \mathrm{l})=20.2\left(\mathrm{~A}_{645}\right)+8.02\left(\mathrm{~A}_{663}\right)
\end{gathered}
$$

Then carotenoid content can be calculated as following:

$$
\operatorname{Car}(\mathrm{mg} / \mathrm{l})=\mathrm{A}_{480} \times 200
$$

The pigment concentration was calculated in $\mathrm{mg} / \mathrm{g} \mathrm{FW}$ of samples.

Table 1. Physical and chemical properties of soil and irrigation water

\begin{tabular}{c|c|c|c}
\hline & & Irrigation water & Soil \\
\hline PH & & 7.1 & 8.40 \\
$\mathbf{E C}(\mathbf{d S} / \mathbf{m})$ & & 7.0 & 9.1 \\
\hline Soluble & $\mathrm{Ca}^{2+}$ & 3.6 & 35.0 \\
Cations & $\mathrm{Mg}^{2+}$ & 0.5 & 19.5 \\
meq/L & $\mathrm{Na}^{+}$ & 3.2 & 34.3 \\
& $\mathrm{~K}^{+}$ & 0.114 & 2.0 \\
\hline Soluble & $\mathrm{CO}_{3}^{-2}$ & 0 & 0.125 \\
Anions & $\mathrm{HCO}_{3}^{-}$ & 1.0 & 3.5 \\
meq/L & $\mathrm{Cl}^{-}$ & 4.7 & 56.3 \\
& $\mathrm{SO}_{4}^{-2}$ & 1.71 & 21.9 \\
\hline & Saturation point \% & & 27.3 \\
& Pot capacity (at 1 bar) & & 13.6 \\
& Wilting point (at 15 bar) & & 6.8 \\
\hline
\end{tabular}

Extraction and determination of proline were directed according to the techniques described by Bates et al. (1973). Plant tissues $(0.5 \mathrm{~g})$ were homogenized with $5 \mathrm{ml}$ of $3 \%$ sulfosalicylic acid and the homogenates were centrifuged at $3000 \times \mathrm{g}$ for $20 \mathrm{~min}$. One $\mathrm{ml}$ of the supernatant was mixed with $1 \mathrm{ml}$ acid ninhydrin reagent and $1 \mathrm{ml}$ of glacial acetic acid in a test tube and incubated in $100^{\circ} \mathrm{C}$ in water bath for $1 \mathrm{~h}$, and then the absorbance value at $520 \mathrm{~nm}$ was noted. Free proline content in sample is determined by referring to a proline standard curve of known concentrations and the results were expressed as $\mu \mathrm{mol}$ proline $\mathrm{g}^{-1} \mathrm{FW}$ (fresh weight). 
For extraction and analysis of antioxidant enzymes, leaf samples $(0.5 \mathrm{~g}$ fresh weight, FW) were homogenized in $3 \mathrm{ml}$ extraction buffer $(0.1 \mathrm{M}$ pH 7.0 potassium phosphate buffer, $1 \mathrm{mM}$ EDTA, $0.05 \%$ Triton $\mathrm{X}-100$ ) in a pre-chilled pestle and mortar, centrifuged at $15,000 \mathrm{~g}$ for $20 \mathrm{~min}$ at $4{ }^{\circ} \mathrm{C}$. The supernatant was used for the estimation antioxidant enzyme activities. Superoxide dismutase activity (SOD EC 1.15.1.1) activity was estimated by the ability of this enzyme to impede the photochemical decrease of nitrobluetetrazolium salt (NBT). The SOD activity was measured at $560 \mathrm{~nm}$ according to the technique of Beyer and Fridovich (1987) and the assays were carried

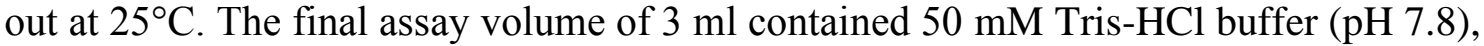
$33 \mu \mathrm{M}$ NBT, $10 \mathrm{mM}$ L- methionine, $0.66 \mathrm{mM}$ disodium EDTA, $0.0033 \mathrm{mM}$ riboflavin and $50 \mu 1$ of supernatant. Reaction was underway under fluorescent light for 15 minutes by adding $10 \mu \mathrm{l}$ of riboflavin solution. One unit of antioxydant SOD was defined as the amount of enzyme activity that inhibited the photo reduction of NBT to blue formazan by $50 \%$. The SOD activity of each extract was expressed as $\mathrm{Ug}^{-1} \mathrm{FW}$. Peroxidase (POX) activity was estimated by the method of Sakharov and Ardila (1999). Peroxidase enzyme activity was determined by the oxidation of guaiacol in the presence of $\mathrm{H}_{2} \mathrm{O}_{2}$. The increase in absorbance was recorded at $470 \mathrm{~nm}$ for 1 min with a spectrophotometer. The reaction mixture contained $50 \mu \mathrm{l}$ of $28 \mathrm{mM}$ guaiacol, $900 \mu \mathrm{l}$ of $50 \mathrm{mM}$ potassium phosphate buffer $(\mathrm{pH} 6.0), 50 \mu \mathrm{l}$ of $5 \mathrm{mM} \mathrm{H}_{2} \mathrm{O}_{2}$, and $10 \mu \mathrm{l}$ of crude extract. POX activity of the extract was expressed as the POX $\mathrm{Ug}^{-1} \mathrm{FW}$. Catalase (CAT EC 1.11.1.6) activity was measured spectrophotometrically according to the method of Aebi (1974). The disappearance of $\mathrm{H}_{2} \mathrm{O}_{2}$ were determined at $240 \mathrm{~nm}$ wavelength in a mixture

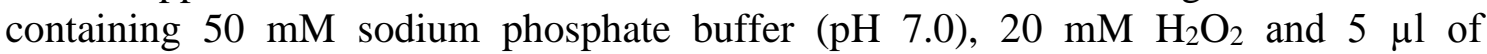
supernatant. The decrease in the absorption was followed for 1 min at $240 \mathrm{~nm}$, and $1 \mathrm{mmol} \mathrm{H}_{2} \mathrm{O}_{2}$ oxidized $\mathrm{ml}^{-1} \mathrm{~min}^{-1}$ was defined as $1 \mathrm{U}$ of CAT activity. Ascorbate peroxidase (APX EC 1.11.1.11) content was determined according to the means of Wang et al. (1991). The mixture contained in a test tube, $50 \mathrm{mM} \mathrm{pH} 7.0$ potassium phosphate buffer, $0.5 \mathrm{mM}$ ascorbic acid, $0.1 \mathrm{mM}$ hydrogen peroxide, and $20 \mu \mathrm{l}$ of enzyme extract were added in a total volume of $1 \mathrm{ml}$. The concentration of oxidized ascorbate was calculated by the decrease in absorbance at $290 \mathrm{~nm}$. The absorption coefficient was $2.8 \mathrm{mM}^{-1} \mathrm{~cm}^{-1}$. One unit of APX was counted as $1 \mathrm{mmol} \mathrm{ml} l^{-1}$ ascorbate oxidized $\mathrm{min}^{-1}$.

\section{Statistical procedures}

Data obtained were subjected to statistical Analysis Of Variance (ANOVA), according to Gomez and Gomez (1984). Averages of the main effects of stress water irrigation were associated using the revised Least Significant Difference test (LSD) method at 0.05 probability level. Computations and statistical analysis were done using Statistical Analysis System computerized package program (SAS).

\section{Results and discussion}

The statistical analysis of variance for the resulting data showed that, the four water stress levels had significant differences on the all physiological studied traits except nitrogen percentage in regard to the examined genotype eggplant (Table 2). Studied plants content of Potassium (K), Phosphorous (P), Carbon (C) and Nitrogen (N) were measured. Results show that highest average of potassium $(14.30 \mathrm{mg} / \mathrm{g} \mathrm{DW})$ was obtained from irrigation treatment with $80 \%$ of pot capacity (T2), while the lowest 
$(6.13 \mathrm{mg} / \mathrm{g} \mathrm{DW})$ was recorded by the irrigation treatment with $60 \%$ of pot capacity (T3) without any significant differences with (T4) $40 \%$ of pot capacity $(6.23 \mathrm{mg} / \mathrm{g} \mathrm{DW})$. There was significant difference in Phosphorous content between treatments, highest was in T2 by $(54.9 \mathrm{mg} / \mathrm{g} \mathrm{DW})$, while the lowest was $(19.53 \mathrm{mg} / \mathrm{g} \mathrm{DW})$. Similar trend was obtained with carbon content, where the highest value $(37.61 \mathrm{mg} / \mathrm{g} \mathrm{DW})$ was obtained by (T2) and the lowest value ( $31.54 \mathrm{mg} / \mathrm{g}$ DW) was obtained by (T4). The water stress treatments resulted in no significant (at $\mathrm{P}<0.05$ ) regarding to nitrogen percentage in all treatments. Eggplant total yield affected by leaf $\mathrm{N}$ and decreased at the lowest irrigation rate 33\% Etc (Díaz-Pérez and Eaton, 2015). In general, T2 shows the highest values of mineral content NPK. Farghali and El-Sharkawl (1988) found that total $\mathrm{K}^{+}$content in Cotton seedlings roots and aerial parts increased progressively with decreasing water stress, particularly under light condition. Data are agree with Kirnak et al. (2001) whose, found that nutrient concentrations in mature leaves of eggplants grown in pots under different irrigation treatments decrease according to water stress levels. In addition, Almohisen (2015) found that similar trend with Carbon, Potassium, Phosphorous content and Nitrogen percentage in tomato.

The effect of water stress treatments on total chlorophyll, chlorophyll a, chlorophyll $\mathrm{b}$ and total carotenoids resulted in significant decrease (at $\mathrm{P}<0.05)$ in accumulation of pigments. Total chlorophyll was $(1.17,0.70,0.92$, and $0.76 \mathrm{mg} / \mathrm{g} \mathrm{FW})$ in T1, T2, T3 and T4 of water stress, respectively. Kirnak et al. (2001) found that total chlorophyll content in water stress treatment was lowered by $55 \%$ compared to control treatment. Regarding to chlorophyll a data obtained was $(0.80,0.36,0.36$ and $0.30 \mathrm{mg} / \mathrm{g} \mathrm{FW})$ for the four water deficit treatments; T1, T2, T3 and T4, respectively. The highest value of chlorophyll b was $0.38 \mathrm{mg} / \mathrm{g} \mathrm{FW}$ in both $\mathrm{T} 1$ and $\mathrm{T} 4$, on the other side, T3 gave the lowest value $(0.38 \mathrm{mg} / \mathrm{g} \mathrm{FW})$. Chlorophyll indexes have been used as subsidiary estimators of chlorophyll content and leaf nitrogen concentrations (Liu et al., 2006). Carotenoids decreased dramatically in response to water stress from $8.65 \mathrm{mg} / \mathrm{g} \mathrm{FW}$ in $\mathrm{T} 1$ (control treatment) to $5.84 \mathrm{mg} / \mathrm{g} \mathrm{FW}$ in the fourth treatment (the most stress).

Regarding the proline content, as mentioned in the first paragraph of results and discussion, the analysis of variance data showed that, the three water stress treatments $(40,60,80 \%)$ had significant effect on increasing proline accumulation compared to control. Data showed that proline was 3.63, 6.24, 5.42 and $5.42 \mu \mathrm{mol} \mathrm{g}^{-1} \mathrm{FW}$ in T1, T2, $\mathrm{T} 3$ and $\mathrm{T} 4$, respectively. In response to water stress, proline accumulation usually occurs in the cytosol which plays a significant role in adjustment of cytoplasmic osmotic (Anjum et al., 2012; Almohisen, 2015). In this study, the higher levels of proline accumulation in T4 followed by $\mathrm{T} 3$ then $\mathrm{T} 2$ enabled the water-stressed plants to maintain low water potentials. Data in Table 2 show the effect of four water stress treatment on four enzymes content in eggplants. Peroxidase was $15.77 \mathrm{Ug}^{-1} \mathrm{FW}$ in control treatment (T1, 0\% water deficit), in treatment number two (T2, 20\% water deficit) Peroxidase was $2.64 \mathrm{Ug}^{-1} \mathrm{FW}$, while it was 36.76 and $12.45 \mathrm{Ug}^{-1} \mathrm{FW}$ in (T3, $40 \%$ water deficit) and (T4, 60\% water deficit), respectively. Ascorbate peroxidase and Catalase decreased significantly with water stress from 1.76 and $430.15 \mathrm{Ug}^{-1} \mathrm{FW}$ in control treatment (T1) to 0.54 and $109.45 \mathrm{Ug}^{-1} \mathrm{FW}$ in $\mathrm{T} 4$ (the high level from water scarcity), respectively. On the other hand, superoxide dismutase values varied significantly, where the accumulation of superoxide dismutase was 21.66, 28.49, 14.56 and $27.37 \mathrm{Ug}^{-1} \mathrm{FW}$ in $\mathrm{T} 1, \mathrm{~T} 2, \mathrm{~T} 3$ and T4, respectively. On the other hand, superoxide dismutase values varied significantly, where the accumulation of superoxide dismutase was $21.66,28.49,14.56$ and $27.37 \mathrm{Ug}^{-1} \mathrm{FW}$ in $\mathrm{T} 1, \mathrm{~T} 2, \mathrm{~T} 3$ and $\mathrm{T} 4$, respectively. 
Table 2. Some physiological characters of studied genotype eggplant in response to water deficit

\begin{tabular}{|c|c|c|c|c|c|c|c|c|c|c|c|c|c|}
\hline Chapter & $\mathbf{K}$ & $\mathbf{P}$ & C & $\mathbf{N \%}$ & \multirow{2}{*}{$\begin{array}{c}\text { Total } \\
\text { Chlorophyll } \\
(\mathrm{mg} / \mathrm{g} \text { FW) }\end{array}$} & \multirow{2}{*}{$\begin{array}{c}\text { Chlorophyll a } \\
\text { (mg/g FW) }\end{array}$} & \multirow{2}{*}{$\begin{array}{c}\text { Chlorophyll b } \\
\text { (mg/g FW) }\end{array}$} & \multirow{2}{*}{$\begin{array}{c}\text { Carotenoids } \\
\text { (mg/g FW) }\end{array}$} & \multirow{2}{*}{\begin{tabular}{|c|}
$\begin{array}{c}\text { Proline } \\
\left(\mu \mathrm{mol} \mathrm{g} \mathbf{g}^{-1}\right. \\
\text { FW })\end{array}$ \\
\end{tabular}} & \multirow{2}{*}{$\begin{array}{r}\text { Peroxidase } \\
\left(\mathbf{U g}^{-1} \text { FW }\right)\end{array}$} & \multirow{2}{*}{$\begin{array}{l}\text { Ascorpate } \\
\text { peroxidase } \\
\left(\mathbf{U g}^{-1} \mathrm{FW}\right) \\
\end{array}$} & \multirow{2}{*}{$\begin{array}{c}\text { Catalase } \\
\left(\mathbf{U g}^{-1}\right. \\
\mathbf{F W}) \\
\end{array}$} & \multirow{2}{*}{$\begin{array}{c}\begin{array}{c}\text { Superoxide } \\
\text { dismutase } \\
\left(\mathbf{U g}^{-1} \text { FW }\right)\end{array} \\
\end{array}$} \\
\hline Treatments & \multicolumn{4}{|c|}{ (mg/g DW) } & & & & & & & & & \\
\hline $\mathrm{T} 1$ & 6.90 & 23.70 & 36.71 & 1.68 & 1.17 & 0.80 & 0.38 & 8.65 & 3.63 & 15.77 & 1.76 & 430.15 & 21.66 \\
\hline $\mathrm{T} 2$ & 14.30 & 54.90 & 37.61 & 1.75 & 0.70 & 0.36 & 0.33 & 8.76 & 6.24 & 2.64 & 1.13 & 383.46 & 28.49 \\
\hline $\mathrm{T} 3$ & 6.13 & 29.33 & 35.71 & 1.73 & 0.92 & 0.63 & 0.28 & 6.85 & 5.42 & 36.76 & 0.63 & 239.26 & 14.56 \\
\hline $\mathrm{T} 4$ & 6.23 & 19.53 & 31.54 & 1.32 & 0.76 & 0.30 & 0.38 & 5.84 & 8.11 & 12.45 & 0.54 & 109.45 & 27.37 \\
\hline F test & $*$ & $*$ & $*$ & ns & $*$ & $*$ & $*$ & $*$ & $*$ & $*$ & $*$ & $*$ & $*$ \\
\hline L.S.D at $0.5 \%$ & 0.353 & 0.602 & 1.858 & -- & 0.127 & 0.005 & 0.024 & 0.118 & 0.152 & 0.359 & 0.107 & 1.696 & 0.650 \\
\hline
\end{tabular}

T1: $100 \%, \mathrm{~T} 2: 80 \%, \mathrm{~T} 3: 60 \%, \mathrm{~T} 4: 40 \%$, of pot capacity *: significant at 5\% level of probability and ns: not significant 
Drought stress brought different variations in the anti-oxidative enzymes activities (Anjum et al., 2012). Moreover, it has been reported that peroxidase, and catalase activities showed an increased or stabled in the early level of drought and then decreased with progression of water stress. It is conspicuous that, higher levels of antioxidants are interrelated to tolerance of plant toward water stress (Tahi et al., 2008). Superoxide dismutase is considered to form the first line of protection against reactive oxygen species (ROS), which catalyzed the superoxide radical $\left(\mathrm{O}_{2^{-}}\right)$to $\mathrm{O}_{2}$ and $\mathrm{H}_{2} \mathrm{O}_{2}$ which are further quenched by diverse antioxidant enzymes.

These significant differences between all values for leaf chlorophyll, carotenoids, proline, enzyme activity and nutrients elements as impact to water stress treatments that may be reflecting the role of these components as a biological regulator in plant (ElSaidy et al., 2011; Ahanger et al., 2016), and may be due to the roll of each one in metabolism system in plant, plus the partial inhibition co-with vitamins of a few interaction in reactive oxygen species production (Ratnakar and Rai, 2013; Ahanger et al., 2017).

\section{Conclusion}

In Considering the previous results as a whole and in regard to the examined genotype, it can be concluded that, there are different physiological changes for all studied tratis exeptonly one ( $\mathrm{N}$ contant) in response to drought stress treatments. The results indicate that irrigation treatment with $80 \%$ of pot capacity (T2) more effectively than $60 \%$ of pot capacity (T3) and $40 \%$ of pot capacity (T4) from the standpoint of more efficient water use. Which would help to diminish drought injury, retain healthy plants to achieve optimum performance and adaptation under drought stress and saving irrigation water usage by $20 \%$.

Change history: The online version of this paper was modified on $27^{\text {th }}$ April 2020. In the following sentence of the Abstract the last percentage data was mistyped (it was corrected from 20\% to $40 \%$ ): "Drought stress treatment had been done by irrigating the plants with $80 \%, 60 \%$ and $40 \%$ of water needed to reach soil pot capacity, plus normal irrigation (control treatment)."

\section{REFERENCES}

[1] Abd El-Ghany, H. M., Nawar, A. A., Ibrahim, M. E., El-Shamarka, Sh. A., Selim, M. M., Fahmi, A. I. (2004): Using tissue culture to select for drought tolerance in bread wheat. http://www.cropscience.org.au/icsc2004/poster/3/4/2/563_hatam.htm\#TopOfPage.

[2] Aebi, H. (1974): Catalase. - Methods of Enzymatic Analysis. - Elsevier.

[3] Ahanger, M. A., Akram, N. A., Ashraf, M., Alyemeni, M. N., Wijaya, L., Ahmad, P. (2016): Signal transduction and biotechnology in response to environmental stresses. Biologia Plantarum 61: 401-416.

[4] Ahanger, M. A., Akram, N. A., Ashraf, M., Alyemeni, M. N., Wijaya, L., Ahmad, P. (2017): Plant responses to environmental stresses - from gene to biotechnology. - AoB Plants 9(4):plx025.

[5] Almohisen, I. A. A. (2015): Effect of Water Stress on Growth and Physiology of Tomato (Lycopersicon esculentum Mill.). - Hortscience Journal of Suez Canal University 4: 1-5.

[6] Anjum, S. A., Saleem, M. F., Wang, L.-C., Bilal, M. F., Saeed, A. (2012): Protective role of glycinebetaine in maize against drought-induced lipid peroxidation by enhancing capacity of antioxidative system. - Australian Journal of Crop Science 6: 576. 
[7] Arnon, D. I. (1949): Copper enzymes in isolated chloroplasts. Polyphenoloxidase in Beta vulgaris. - Plant physiology 24: 1-15.

[8] Bates, L. S., Waldren, R. P., Teare, I. D. (1973): Rapid determination of free proline for water-stress studies. - Plant and Soil 39: 205-207.

[9] Beyer, W. F., Fridovich, I. (1987): Assaying for superoxide dismutase activity: Some large consequences of minor changes in conditions. - Analytical Biochemistry 161: 559566.

[10] Bock, R. (1984): A handbook of decomposition methods in analytical chemistry. International Textbook Co, 444p.

[11] Buhtz, A., Hohe, A., Schwarz, D., Grosch, R. (2017): Effects of Verticillium dahliae on tomato root morphology considering plant growth response and defense. - Plant Pathol. 66: 667-676.

[12] Cassel, D., Nielsen, D. (1986): Field capacity and available water capacity. - In: Klute, A. (ed.) Methods of Soil Analysis: Part 1-Physical and Mineralogical Methods, SSA Book Series 5.1: 901-926.

[13] Chaves, M. M. (1991): Effects of Water Deficits on Carbon Assimilation. - Journal of Experimental Botany 42: 1-16.

[14] Cornic, G., Massacci, A. (1996): Leaf photosynthesis under drought stress. Photosynthesis and the Environment. Springer.

[15] Díaz-Pérez, J. C., Eaton, T. E. (2015): Eggplant (Solanum melongena L.) plant growth and fruit yield as affected by drip irrigation rate. - HortScience 50: 1709-1714.

[16] Doorenbos, J. (1975): Guidelines for predicting crop water requirements. - Food and Agriculture organization, Rome. FAO Irrig. Drainage paper 24.

[17] El-Saidy, A. E. A., Farouk, S., Abd El-Ghany, H. M. A. (2011): Evaluation of Different Seed Priming on Seedling Growth, Yield and Quality Components in Two Sunflower (Helianthus annuus L.) Cultivars. - Trends in Applied Sciences Research 6: 977-991.

[18] Farghali, K., El-Sharkawl, H. (1988): Interactive Effects of NPK Nutrients, Water Potential and Irradiance on Contents of Potassium and Phosphate in Cotton Seedlings. Phyton 28: 171-181.

[19] Gaveh, E. A., Timpo, G. M., Agodzo, S. K., Shin, D. H. (2011): Effect of irrigation, transplant age and season on growth, yield and irrigation water use efficiency of the African eggplant. - Horticulture, Environment, and Biotechnology 52: 13-28.

[20] Gomez, K. A., Gomez, A. A. (1984): Statistical procedures for agricultural research. John Wiley \& Sons.

[21] Gupta, A., Dixit, S. K., Senthil-Kumar, M. (2016): Drought stress predominantly endures Arabidopsis thaliana to Pseudomonas syringae infection. - Front. Plant Sci. 7: 808-819.

[22] Karam, F., Saliba, R., Skaf, S., Breidy, J., Rouphael, Y., Balendonck, J. (2011): Yield and water use of eggplants (Solanum melongena L.) under full and deficit irrigation regimes. - Agricultural Water Management 98: 1307-1316.

[23] Kirnak, H., Kaya, C., Tas, I., Higgs, D. (2001): The influence of water deficit on vegetative growth, physiology, fruit yield and quality in eggplants. - Bulg. J. Plant Physiol 27: 34-46.

[24] Klute, A., Gee, G. W., Bauder, J. W. (1986): Particle-size Analysis. - SSSA Book Series. Soil Science Society of America, American Society of Agronomy.

[25] Kurniawati, S. (2014): Drought Stress Tolerance Mechanisms of Eggplant (Solanum spp.): Physiology and Molecular. - Institut Pertanian Bogor, Scientific Repository.

[26] Liu, Y. J., Tong, Y. P., Zhu, Y. G., Ding, H., Smith, E. A. (2006): Leaf Chlorophyll Readings as an Indicator for Spinach Yield and Nutritional Quality with Different Nitrogen Fertilizer Applications. - Journal of Plant Nutrition 29: 1207-1217.

[27] Molden, D. (1997): Accounting for water use and productivity, SWIM Paper 1, systemwide initiative for water management. - International Water Management Institute, Colombo, Sri Lanka, 16. 
[28] Molden, D., Sakthivadivel, R., Habib, Z. (2001): Basin-level use and productivity of water: Examples from South Asia. - IWMI.

[29] Ratnakar, A., Rai, A. (2013): Influence of $\mathrm{NaCl}$ salinity on $\beta$-carotene, thiamine, riboflavin and ascorbic acid contents in the leaves of Atriplex hortensis L. var. Pusa Bathua No. 1. - Journal of Stress Physiology \& Biochemistry 9: 187-192.

[30] Rhoades, J. (1982): Soluble salts. - In: Page, A. L., Miller, R. H., Keeney, D. R. (eds.) Methods of soil analysis. Part 2: 167-178.

[31] Richards, L. A. (1969): Diagnosis and improvement of saline and alkali soils. - United States Department Of Agriculture; Washington.

[32] Sakharov, I. Y., Ardila, G. B. (1999): Variations of peroxidase activity in cocoa (Theobroma cacao L.) beans during their ripening, fermentation and drying. - Food Chemistry 65: 51-54.

[33] Tahi, H., Wahbi, S., El Modafar, C., Aganchich, A., Serraj, R. (2008): Changes in antioxidant activities and phenol content in tomato plants subjected to partial root drying and regulated deficit irrigation. - Plant Biosystems - An International Journal Dealing with all Aspects of Plant Biology 142: 550-562.

[34] Tani, E., Kizis, D., Markellou, E., Papadakis, I., Tsamadia, D., Leventis, G., Makrogianni, D., Karapanos, I. (2018): Cultivar-Dependent Responses of Eggplant (Solanum melongena L.) to Simultaneous Verticillium dahliae Infection and Drought. Front Plant Sci. 9: 1181-1192

[35] Wang, S. Y., Jiao, M., Faust, M. (1991): Changes in ascorbate, glutathione, and related enzyme activities during thidiazuron-induced bud break of apple. - Physiologia Plantarum 82: 231-236. 